\title{
Market Orientation Impact on Radical and Incremental Marketing Innovation: A Study of Saudi Arabia Hospital Marketing Efforts
}

\author{
Alshahry Abdullah saeed A, Wang Aimin \\ School of Management, Wuhan University of Technology, Wuhan, China \\ Email (corresponding author): aboodi_besha@ hotmail.com
}

\begin{abstract}
We conducted an empirical study to measure influence of market orientation on marketing innovation in hospitals in Saudi Arabia. The sample includes 109 hospital workers that have been identified as having an adequate knowledge of the subject of research. In particular we explain the impact of customer orientation, inter-functional orientation and competitor orientation on marketing innovation. Furthermore the moderating effects of centralization and formalization on those relationships are explained. The findings of our study suggest that there is an important role of market orientation for the successful implementation of innovation and business performance of hospitals in Saudi Arabia. The results indicated that there is a positive influence of customer orientation on radical innovation and incremental innovation, a strong positive impact of competitor orientation on incremental innovation and no significant impact regarding inter-functional coordination on both incremental and radical innovation. The moderating effect of centralization on market innovation and innovation proved to be insignificant and the formalization effect had a positive influence on the customer, competitor and inter-functional orientation and radical innovation relationship. Additionally our study is valuable (for the practice, and theory) as it assisted in developing and further elaborating the science of market orientation, particularly customer and competitor orientation and inter-functional coordination, and the influence on incremental and radical service which are relevant for the financial results of hospitals in Saudi Arabia. The contribution of this research was also to develop a conceptual and theoretical understanding on incremental and radical innovation in the effort to improve performance, especially for the Saudi Arabian hospitals. The practical implication of this study is the insight and the knowledge Saudi Arabian hospital managerial staff, in implementing the concept of market orientation in relation to innovation and overall hospital performance.
\end{abstract}

Keywords: Market orientation, Radical Marketing Innovation, Incremental Marketing Innovation, Centralization, Formalization, Saudi Arabia

\section{Introduction}

With the privatization of the health sector and an overall trend in health care where the servicing of the patients and illness prevention is becoming a major source of industry's revenue, attracting new customers and marketing innovation are becoming increasingly relevant for organizational performance and financial results of hospitals. Consequently, offering an innovative and superior marketing mix for the customers is a necessary requirement for market competitiveness. Marketing operations and market orientation should therefore be aimed at boosting the marketing innovation of hospitals.

This research examines factors that businesses should focus on in order to achieve sufficient levels of marketing innovation that are crucial of organizational performance. A market orientated company puts the customer at the 


\section{Alshahry Abdullah saeed A, Wang Aimin \\ Market Orientation Impact on Radical and Incremental Marketing Innovation: A Study of Saudi Arabia Hospital Marketing Efforts}

"heart" of the business. (Kohli \& Jaworski, 1990; Narver \& Slater, 1990); all activities in the organization are based around the customer.

There has not been sufficient research of what leads to marketing innovation in a service sector; but we know it is rather significant for performance of firms. In the last decades, we have seen an evolution of the service sector's role in the economy, its relevance increasing in innovation, competitiveness, employment and economic growth (Hauknes, 1998; de Jong, Bruins, Dolfsma and Meijaard, 2003; Howells and Tether, 2004; Tether, 2005). From the growing relevance of this sector, it becomes important to analyze the determinant factors of innovative capability in firms in general and service firms in particular. However, despite its obvious importance, and unlike product or process innovation, marketing innovation has received little attention in the economics literature. The purpose of this paper is to make a contribution to the empirical analysis of marketing innovation and explore the variables that influence the marketing innovation process. From approach of services as a not very innovative sector that "absorbed" innovation from the manufacturing sector, various authors and organizations have considered services as possessing their own forms of innovation, and in some cases, with high levels of innovation (Evangelista, 2006). The increased interest in investigating the service sector has been obvious in recent decades, aiming to develop the necessary knowledge for increased productivity and innovation in this sector (Grönroos, 2000,,Ark and Van, 2003).

The hospital sector in Saudi Arabia is not so much market oriented and needs to be so in order to foster innovation. Firstly, it is required to build a robust and comprehensive measure of market orientation (especially as it applies to the health care industry). In addition, the relationship of long-term focus and profit orientation components with the three component model of market orientation advanced by Narver and Slater (1990) also to be examined. It is also important to examine the market orientation-performance relationship in a context specific setting of the health care industry, thus controlling for industry effects (Dess, Ireland, \& Hitt, 1990), an aspect ignored in prior studies. The study also sought to identify variables that are unique to the hospital industry, and could affect the market orientation-performance relationship. By examining the market orientation-performance relationship in a "context-specific" setting In Saudi Arabian Armed Forces Hospital as the sample, the present study would not only extend the generalizability of findings generated in "context-free" (Blair \& Boal, 1991) situations, but also provide evidence for the applicability of an important strategic management and marketing concept to the field of health care management. The importance of market orientation to business performance has been underscored in the strategic management and marketing literatures for long; ascertaining its applicability to health care organizations should provide important pointers to health care professionals as they try to make their organizations more effective and efficient.

It is not entirely clear how to apply certain processes i.e. how this orientation depends on the level of centralization and formalization. To test the market orientation-performance relationship among hospitals in a comprehensive and industry-relevant way, different aspects were employed in the present study in order to better understand the relationship. (Arundel, Kanerva, Cruysen, Hollanders, 2007) A market oriented hospital is expected to use its market information to achieve operating efficiency because it is likely that such a firm understands that value can be created for buyers not only by additional benefits to them but also by reducing their acquisition and use costs (Narver and Slater 1990). When we examine different aspects in the orientation process and how they really depend on centralization and formalization effects, we have to ask ourselves how these processes have an effect on the performance outcome. Depending on the actual level of centralization can prove to be a challenge for numerous companies, including hospitals and healthcare institutions and facilities because it is yet unclear how centralization can influence the outcome or performance of a certain company and does a high level of centralization or decentralization render a company more productive or efficient. It is also vital to establish how the process of formalization, i.e. different organization's policies, procedures, job descriptions, and rules effect orientation. Our aim is to explore how different variables, that is, consumer and competitor orientation, interfunctional coordination, centralization and formalization affect and correlate with radical and incremental marketing innovation, the factors which influence such a process and the strength of the connection of these variables, all this within the hospitals in southern region of Saudi Arabia.

This research will address the link between market orientation variables and radical and incremental marketing innovation, how the aforementioned orientations affect the innovation process itself. Also, another objective of the study is to determine the current state of marketing innovation in the Saudi Arabian hospitals, This study will address 


\section{Alshahry Abdullah saeed A, Wang Aimin \\ Market Orientation Impact on Radical and Incremental Marketing Innovation: A Study of Saudi Arabia Hospital Marketing Efforts}

the problem of insufficient investigation of the innovation system. The ultimate objective is however to enable the hospitals to achieve higher performance.

\section{Prior research and model construction}

The foregoing analysis of the literature examined the value of market orientation variables and their link with radical and incremental innovation and the relationship and relationship and tested a moderating effect of formalization and centralization on the relationship between market orientation variables and innovation variables) with the processes of centralization and formalization, i.e., to try and establish the connection on how activities of an organization, particularly those regarding planning and decision-making, become concentrated within a particular group or keeping all of the important decision-making powers within head office or the center of the organization and depending on how work roles are structured within an organization. We utilized already defined theories in order to conduct our empirical research and investigation. All the theories and relationships of the variables our model contains are explained and the constructs in this model are all carefully elaborated. In order to reach the objective of the study and answer the research question, we took several variables of market orientation and analyzed the relationship between them. Based upon the literature, the hypothesized model elaborates the relationship between customer orientation, competitor orientation and inter-functional coordination on radical incremental innovation through the centralization and formalization process. There is a growing interest in the concept of market orientation, as empirical evidence shows that firms with a higher market orientation obtain better market performance, thus optimizing their economic and commercial results. When a company tries to expand and deepen current customer relationships and the orientation that specific firm has to take when developing new customer relationships, has the potential to significantly impact overall firm performance (Kumar et al. 2011; Morgan and Hunt 1994; Palmatier et al. 2009).

\section{Customer orientation and radical innovation}

Customer orientation is defined as an approach to sales and customer-relations in which staffs focus on helping customers to meet their long-term needs and wants. Here, management and employees align their individual and team objectives around satisfying and retaining customers. (Olshavsky and Spreng (1996). Customer orientation refers to a group of actions taken by a company to support the needs of its clients by engaging sales and support staff in order to ensure customer satisfaction is the major priority. A customer-oriented organization places customer satisfaction at the core of each of its business decisions. This contrasts, in part, with a sales orientation, which is a strategic approach where the needs and wants of the firm or salesperson are valued over the customer. The overall point of customer orientation, both internal and external, is to raise profits and increase productivity.

Radical innovation creates brand new values through innovative concept and is fabricated to meet the needs of emerging customers and markets, and offer new designs, create new markets, or develop new channels of distribution (Jansen et al., 2006). The negative influence of market orientation, especially on radical innovations, has already been detected (Bennett and Cooper 1979; Lawton and Parasuraman 1980). Lawton and Parasuraman (1980) revealed in a study that the adoption of the marketing concept did not affect the success of new product ideas in the market or the innovativeness of new product offerings. Although past studies emphasize that inventions can be turned into successful innovations when they fulfill customer needs and reach the right customers at right time (e.g., Holt et al., 1994) the importance of radical innovations is widely spread as they are crucial to the long term survival of many firms (McDermott \& O'Connor, 2002) by providing the foundation on which future generations of products are created. Market orientation is important for innovative firms that seek superior competitive advantage but in radical innovations this can be extremely difficult since the customers are rarely able to explicitly state their requirements and tend to resist radical solutions which often require changes in their behavior (Sandberg, 2008; van den Hende \& Schoormans, 2012). The problems that arise when dealing with radical innovations are mostly related to customers and markets. These difficulties and constraints have already been largely acknowledged in prior studies but there are still some determinants that require further analysis and that are related to customer orientation that hinder radical innovation activities in firms.

Therefore we hypothesize that:

H1 Customer orientation has a negative impact on radical innovation 


\section{Customer orientation and incremental innovation}

We hypothesize that customer orientation has a positive effect on incremental innovation. The orientation that a firm takes toward deepening current customer relationships, or developing new customer relationships, has the potential to significantly impact overall firm performance (Kumar et al. 2006; Morgan and Hunt 1994; Palmatier et al. 2006). Customer orientation includes more quality in products, firm's commitment, positive word-of-mouth, consumer satisfaction and loyalty. Market orientation enhances customer satisfaction and loyalty because firms are well positioned to anticipate customer needs and offer goods and services to satisfy those needs (Slater \& Narver, 1994). According to (Jansen et al., 2006; Li et al., 1998), incremental innovation is made to meet the needs of existing customers or markets and to broaden existing knowledge and skills, to improve established designs, to expand existing products and services, and to increase the efficiency of existing distribution channels. Incremental innovation tends to limit the range of potential innovation, because it relies on customers' current view of the service market (Becheikh et al., 2006) and is closely related to customer-led strategies. It is important to develop the required skill in order to understand and satisfy the expressed needs of current customers, which in the end leads to an increased competence with these skills and procedures. As a result of the aforementioned, greater competence with skills and procedures for current customers and their expressed needs will increase incremental innovations.

Therefore we hypothesize that:

H2 Customer orientation has a positive impact on incremental innovation

\section{Competitor orientation and radical innovation}

Our hypothesis was that competitor orientation had a positive impact on radical innovation. The importance of radical innovation processes is widely recognized on both the empirical and theoretical levels regarding competitor orientation. Prior research has shown are that strong competitor orientation, a key ingredient of market orientation, has a positive relationship to incremental innovation for start-up companies but it is contra productive for mature companies. (Qureshi, 2008). The case in mature organizations is that a strong competitor orientation is associated with radical innovation though and our research we will try to investigate and further elaborate our hypothesis that competitor orientation has a positive impact on radical innovation in the Saudi Arabian Armed Forces Hospital. According to Narver and Slater competitor orientation, an element of market orientation, means that "a seller understands the shortterm strengths and weaknesses and long-term capabilities and strategies of both the key current and potential competitors". The future of innovation culture on corporate level is based on the provision of conducive environment, contribution of the individuals in the growth of innovative ideas, and self development, which gives birth to a set of innovations which are radical, incremental and learnt from the competitors through proper manner recognized in the corporate world (Qureshi, 2008). In order to create a relationship between the two components of our present hypothesis, it is vital to comprehend that radical innovations in products, services, processes, etc. are breakthroughs that fundamentally change a product or service or process and it is important to comprehend that competitor oriented companies are not just trying to analyze the strengths and weaknesses of current competitors, but are also trying to anticipate the current competitors and potential competitor action.

Therefore we hypothesize that:

\section{H3 Competitor orientation has a positive impact on radical innovation}

\section{Competitor orientation and incremental innovation}

With this hypothesis we have tried to affirm that competitor orientation has a significant positive effect on the incremental innovation. Competitor orientation refers to a firm's ability to identify, analyze, and respond to competitors' actions (Kholi and Jaworski, 1990). The debate as to the effect of competitor orientation on innovation is again not resolved as of yet (Lukas and Ferrell, 2000). Generally, to imitate competitors' new services can be regarded as an attractive source of innovation, leading to minimizing risks and development costs. This implies that competitor oriented service firms would be intended to develop incremental innovation and preclude radical service development. Some researchers agree that competitor orientation is a central source of imitation and results in a negative impact on 


\section{Alshahry Abdullah saeed A, Wang Aimin \\ Market Orientation Impact on Radical and Incremental Marketing Innovation: A Study of Saudi Arabia Hospital Marketing Efforts}

radical innovation (Lukas and Ferrell, 2000). This because focusing too much on competitors will deflect attention from changes in market segment structures and as a result reduces the development of radical innovative abilities (Day and Wensley, 1988; Zhou et al., 2008). Competitor orientation leads to incremental innovations where it gathers information about customer needs, competitors and transfers this information throughout the organization to fully exploit it. Based on this information, existing products are improved on the short term to stay ahead of competitors and incremental innovation allows a company to keep up with competition and hold market position.

We hypothesize that:

H4 Competitor orientation has a positive impact on incremental innovation

\section{Inter-functional coordination and incremental innovation}

According to Narver \& Slater, interfunctional coordination is defined as the integration and collaboration of various functional areas (or departments) within an organization as a way of enhancing communication and information to better meet the organization's goal areas to accommodate disparate views and work around conflicting perspectives and mental models by putting aside functional interests for the better of the organization as a whole We presuppose that interfunctional coordination represents a key form of internal social capital of an organization. Although interfunctional coordination plays a key role in the performance of a company, our hypothesis is it does not significantly improve and existing product or product line new features increasingly desired by consumers, that usually helps maintain or improve its competitive position over time, therefore has no or barely any significance on incremental innovation. Interfunctional coordination has been largely ignored it compared to the other two market orientation components: customer orientation and competitor orientation. (Jansen et al., 2006; Li et al., 2008). The question of whether our current knowledge can be generalized to firms from the developing world has also been neglected since most studies have been conducted in developed countries. Research has confirmed that the difference in the stage of the product life cycle is negatively related to interfunctional coordination. In turn, interfunctional coordination has a positive effect on company performance. It was further determined and emphasized the important role that information exchange plays in achieving inter-functional coordination and the way in which the information is communicated. (Craig and Hart (1992) Also, Pinto and Pinto (1990) further emphasized the connection between communication and functional coordination by suggesting that cross-functional communication was critical to the successful implementation of new product projects. Interfunctional coordination can be understood as a structural mechanism for enhancing common goals in the organization. It can be viewed as a means to foster greater communication, collaboration, and cohesiveness, thereby enhancing the relationships between groups possessing different functional knowledge, experience, and education.

Therefore we hypothesize:

\section{H5 Inter-functional coordination has no significant impact on incremental innovation}

\section{Inter-functional coordination and incremental innovation}

Most authors agree that all three components; customer orientation, competitor orientation and interfunctional coordination are important and provide a holistic view of firms' ability to collect and use market information effectively (e.g., Jaworski and Kohli 1993; Narver and Slater 1990) Interfunctional coordination reflects the level of interaction and communication in the organization (Im and Workman 2004). It is often suggested to have a positive effect on radical innovation consequences because it facilitates dissemination of novel market information and enhances problem solving (Gatignon and Xuereb 1997). 'Too much' collaboration and information sharing, however, often have a negative effect (Henard and Szymanski, 2001). Still, at the heart of interfunctional coordination lies the sharing of market information that is crucial for new product development (Im and Workman 2004). Overall therefore, the positive effect of interfunctional coordination is expected to exceed its negative effect. In order to backup our hypothesis that interfunctional coordination has an overall positive impact on radical innovation it is crucial to underline that importance of radical innovations is considered to be crucial to the long-term survival of many companies. Nevertheless, knowledge on radical innovation development and commercialization is still rather limited (Chiesa \& Frattini, 2011; Cooper, 1993; Leifer et al., 2001), even though it is acknowledged that the technological and market uncertainties create particular, considerable challenges for firms creating radical innovations (Sainio et al., 


\section{Alshahry Abdullah saeed A, Wang Aimin \\ Market Orientation Impact on Radical and Incremental Marketing Innovation: A Study of Saudi Arabia Hospital Marketing Efforts}

2012; McDermott \& O'Connor, 2002; Veryzer, 1998a). Past studies emphasize that inventions can be turned into successful innovations when they fulfil customer needs and reach the right customers at right time (e.g., Holt et al., 1984). Thus, market orientation is important for innovative firms that seek superior competitive advantage (e.g., Atuahene-Gima, 1996; Hurley \& Hult, 1998). However, in radical innovations this can be extremely difficult since the customers are rarely able to explicitly state their requirements and tend to resist radical solutions which often require changes in their behaviour (Sandberg, 2008; van den Hende \& Schoormans, 2012).

\section{H6 Inter-functional orientation has a positive impact radical innovation}

\section{Centralization and formalization effects}

The question is whether a traditional variable which define a firm's organizational structure such as centralization can have a negative moderating effect on the market orientation and marketing innovation relationship. Centralization is defined as "the concentration of decision-making authority typically impairs effectiveness because it increases perceptions of bureaucratic structuring, which decreases the favorability of participants' attitudes toward the project and results in increased opportunism" (Sivadas and Dwyer, 2000: 34). Centralization represents a situation in which all the power for decision-making rests at a single point within the organization. Numerous studies to argue that the centralization may have opposite effect on market orientation (Despande \& Zaltman, 1992) and also facilitates radical innovation adoption because more concentrated power may be needed to overcome opposition to these kinds of changes (Normann 1971), and narrows communication channels (Cardinal 2001) while reducing the quality and quantity of ideas and knowledge retrieved for problem solving. In addition, it decreases the sense of control over work and diminishes the likelihood that unit members seek innovative and new solutions (Atuahene Gima 2003, Damanpour 1991). We could define that the centralization process upholds information-processing efficiency, speeds up innovation processes and in particular supports the development of incremental innovation (Kortmann 2013), opposite of decentralization which supports non-routine problem solving, increases the likelihood that unit members seek innovative and new solutions, as well as enables deviation from existing knowledge. This study explores two types of organizational structure and the impact of each type on innovation: centralization and formalization. (Lukas and Menon, 2004). Jansen et al. (2006) reveal that centralization decreases radical innovation because centralization restricts communication channels between management and staff and reduces idea and solution generation within the development team (Damanpour, 1991; Jaworski and Kohli, 1993; Sheremata, 2000). Therefore we hypothesize that centralization has a negative impact on radical innovation. On the other hand, centralization has a positive impact on incremental innovation (Cardinal, 2001), because the development of incrementally new products typically involves small, less radical change, and improvements to serve customer needs quickly (Jansen et al., 2006) and the speed of decision-making is faster (Sheremata, 2000). This contradiction is important here, because it improves the efficiency of information processing. The hypothesis that centralization accelerates the effects of managerial attitudes toward change on radical innovation adoption does not address whether there is a direct effect of centralization on the adoption of either innovation type. Such an effect has clearly been proposed in the literature: one argument posits a positive and the other a negative relationship. (Damanpour, 1991; Jaworski and Kohli, 1993; Sheremata, 2000). It can be determined that, the higher the level of centralization the weaker the impact of customer orientation will be on incremental innovation. Because incremental innovation requires non-routine problem solving and deviation from existing knowledge, centralization of decision making is likely to reduce incremental innovation. Conversely, previous research has suggested that centralization is beneficial to speeding up incremental innovation (Sheremata 2000). Incremental innovation is limited in scope and newness, and generates less uncertainty about requisites for organizational units (Gopalakrishnan and Damanpour 1994). Therefore we hypothesize:

H7 There is a negative moderating effect of centralization on the market orientation and marketing innovation relationship

The moderating effect of formalization is the design parameter by which the work processes of an organization are standardized. Formalization tends to hinder the generation and dissemination of information and the response implementation (Jaworski and Kohli, 1993). Numerous studies to argue that the formalization may have opposite effect on market orientation (Zaltman et al., 1973; Despande \& Zaltman, 1982). This could be an indication that the increase of centralization could cause a decrease in a company's market orientation, While there has been substantial research 
on both formalization and of the innovation process, relatively little attention has been paid to the relationship between these two constructs. Formalization is the degree to which rules, procedures, instructions, and communications are formalized or written down (Khandwalla 1977). The reliance on rules and procedures hampers experimentation and ad hoc problem-solving efforts (March and Simon 1958), and reduces the likelihood of individuals deviating from structured behavior (Weick 1979). Formalization acts as a frame of reference that constrains exploration efforts and directs attention toward restricted aspects of the external environment (Weick 1979). It hinders deviation from existing knowledge and a unit's variation-seeking behavior. Formalization detrimentally affects radical innovation because formalization constructs a framework in the new product development process that reduces the creation of new ideas and decreases the rate of developing new products (Damanpour, 1991; Vega-Jurado et al., 2008). Formalization restricts the planning for and control of unexpected environments (Salomo et al., 2007). Furthermore, formalization decreases market generation and intelligence dissemination (Jaworski and Kohli, 1993), because it limits attention to diversion from existing knowledge and finding customer needs (Jansen et al., 2006).

Therefore we hypothesize that:

H8 There is a negative moderating effect of formalization on the market orientation and marketing innovation relationship

Figure 2-1 A research model on marketing orientation and innovation relationship

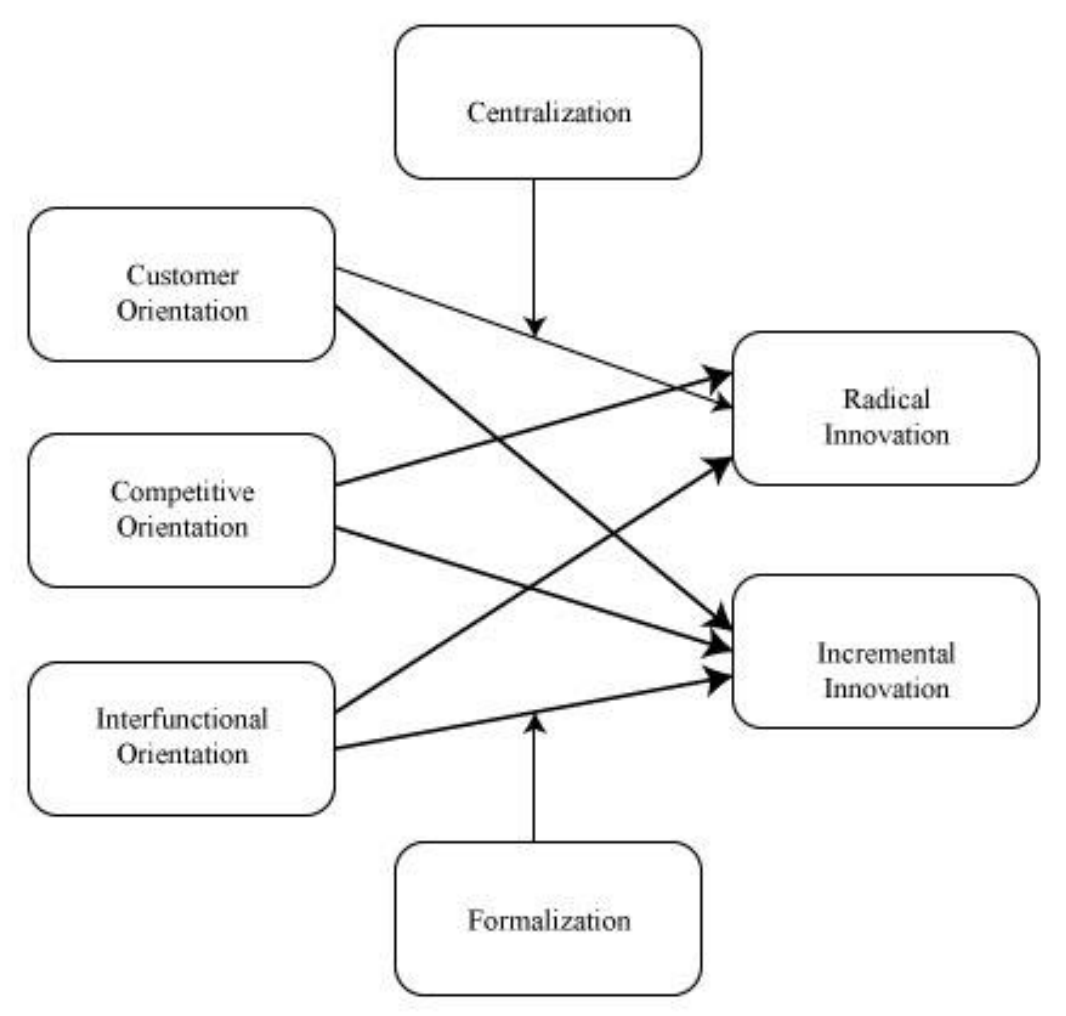

\section{Research methodology}

The sample included members of the Saudi Arabian Hospitals in the country. The principal institutions targeted were the hospitals that enjoyed the highest reputation in the country. The hospitals were deemed as the most important and 


\section{Alshahry Abdullah saeed A, Wang Aimin \\ Market Orientation Impact on Radical and Incremental Marketing Innovation: A Study of Saudi Arabia Hospital Marketing Efforts}

relevant indicator, which would provide reliable data and results. The respondents included key hospital managers and managerial staff from a variety of hospital departments as they were deemed to be most familiar with the factors influencing market innovation. The survey of the hospital staff were carried out through a questionnaire in Survey Monkey to permit a better and therefore more accurate understanding of the different relationships between innovation processes and their influence on market innovation.

The physicians and managerial staff of the Saudi Arabian Hospitals were selected as the data sources. 109 interviewees responded to the questionnaire, which was handed out to more than 350 hospital staff members giving a $31.1 \%$ response rate. The questionnaire was created electronically in Survey Monkey. Clearly, the groups targeted primarily concern represent the direct players in the marketing process, though the end-users can be either the hospital's staff or the patients themselves. Out of the interviewed hospital managerial staff, managers and Heads of department, 94,2\% resulted in being male. A majority of the respondents (60\%) were between the age of 24 and 35. Approximately 47\% of the respondents obtained a Master Degree and 83,5\% of the interviewed respondents had a job occupation at the Armed Forces Hospital. The department mostly consisted of 5-10 members (41,3\%). Our sample of the respondents had mostly managerial functions and occupations (15,7\%), Community and social services occupations $(17,4, \%)$ and administrative and technical occupations, such as education, training, library services, etc. $(16,5 \%)$.

The items measured included customer and competitor orientation, formalization, centralization, interfunctional coordination, radical innovation and incremental innovation. Centralization of decision making was measured by a scale that was adopted from prior studies. They developed the scale by combining two scales developed by Aiken and Hage in 1967 and used sub-construct of hierarchy of authority scale and Dewar in 1980. Some changes in the vocabulary were made in order to fit the context of our research. The scale adopted exhibited sufficient reliability (Cronbach's Alpha $=((\mathrm{a}=.71))$ Centralization of decision making indicates the extent to which decision making is concentrated in an organization (Aiken and Hage 1968). This reflects the extent an employee has to follow the guidelines set by the supervisor and the control which supervisor exerts over employees' decision making. It is measured by a 5 item scale. The formalization process was measured by a scale that was adopted from Innovation antecedents. The scale was developed based on the study previously done by Desphande and Zaltman. Some changes in the vocabulary were performed in order to fit the context of our research. The scale adopted showed sufficient reliability $($ Cronbach's Alpha $=$ ). Formalization indicates the degree to which rules define roles, authority relations, communications, norms and sanctions, and procedures, and also defines the rules and procedures which occupy a central place inside of and organizational unit. (Hall, Haas, and Johnson 1967). It is measured by a 5 item scale. Customer orientation was measured by a scale adopted from Narver and Slater (1990). The scale was developed based on the their definition of the whole marketing orientation process, which they consider to be an organizational culture and as the implementation of the marketing concept. There were several changes in the vocabulary in order for it to correspond to the context of our study. The scale that was shown demonstrated adequate reliability (Cronbach's Alpha $=((\mathrm{a}=.83))$. Customer orientation refers to a group of actions taken by a business to support its sales and service staff in considering client needs and satisfaction their major priorities. According to Kohli and Jaworski (1990), business strategies that tend to reflect a customer orientation might include: developing a quality product appreciate by consumers; responding promptly and respectfully to consumer complaints and queries; and dealing sensitively with community issues. Competitor orientation was measured by a scale adopted from innovation antecedents. It is a combination of two scales developed by Narver and Slater (1990) and by (Despande 1998). There was some modification of vocabulary in order to better adapt the context of our research. The scale adopted showed sufficient reliability (Cronbach's Alpha $=((a=.64))$ Competitor orientation is where the firm directs its resources to gathering information about competitor behavior and activities. The firm's strategies will then be based on the information gathered through any of these orientations. Their results are measured by a 5 item scale. Inter-functional coordination was measured by a scale adopted from innovation antecedents which is a combination of to scales created by by Narver and Slater (1990). There was some modification of the vocabulary in order to better suit the context of our study. The scale adopted demonstrated sufficient reliability (Cronbach's Alpha $=((\mathrm{a}=.80))$ Inter-functional coordination Interfunctional coordination is connected with market orientation and is one of necessary principle of market orientation. It is not possible to use market orientation without inter-functional coordination and the very concept of market orientation is based on marketing conception. Much of the traditional strategic advantages that have served companies so well can generally be reverse-engineered and often at a lesser cost. Their results are measured by a 5 item scale. Radical innovation was measured by a scale adopted from Dewar (2006). It was a combination of scales adapted from 


\section{Alshahry Abdullah saeed A, Wang Aimin \\ Market Orientation Impact on Radical and Incremental Marketing Innovation: A Study of Saudi Arabia Hospital Marketing Efforts}

Avlonitis et al., 2007), There was some modification of the vocabulary in order to better suit the context of our research. The scale that was adopted showed sufficient reliability (Chronbach's Alpha= ((.84)) Radical innovation, concerned with exploration of new technology, is fundamentally different from incremental innovation that is concerned with exploitation of existing technology. According to Dewar "Radical innovation is a product, process, or service with either unprecedented performance features or familiar features that offer potential for significant improvements in performance and cost."1 It creates such a dramatic change in processes, products, or services that they transform existing markets or industries, or create new ones. The results are measured by a 5 item scale. Incremental innovation was measured by a scale adopted from Dewar (2006). It was a combination of scales adapted from Avlonitis et al., 2001). Some changes were made in the vocabulary to better suit the context of our study. The scale that was adopted showed sufficient reliability (Chronbach's Alpha= ((.89)) The process of incremental innovation consists of A series of small improvements to an existing product or product line that usually helps maintain or improve its competitive position over time. According to Kohli and Jaworski, Incremental innovation is regularly used within the high technology business by companies that need to continue to improve their products to include new features increasingly desired by consumers. The results are measured by a 5 item scale.

\section{Results}

As a part of the questionnaire evaluation validity and reliability checks were performed. A reliability check is considered to be a measure of internal consistency and scale reliability. First, Cronbach's Alpha for all variables were calculated and all of them were well above the threshold of 0.7 thus exhibiting sufficient reliability of the measurement instrument and also suggesting that the items have relatively high internal consistency. The maximum value was for customer orientation (.982), and the minimum value for the formalization process (.854). Furthermore Cronbach's Alpha if item deleted was calculated for all items of the questionnaire measuring all latent variables. No item was excluded from the questionnaire, as deleting would not improve reliability of the instrument in any case. Confirmatory factor analysis (CFA) was performed in order to assess the validity of the tool. The objective of confirmatory factor analysis is to test whether the data fit a hypothesized measurement model. Maximum likelihood extraction method was used and twelve factors were extracted. Seven factors of our model explain 84 percent of the variance. An acceptable model should have an RMSEA less than .05. The root mean square error of approximation was calculated using the chi-square test value, the degrees of freedom and the sample size. The result was 0.19225 and according to the RMSEA interpretation guidelines the value is between a close and exact fit. This obtained value further confirmed the construct validity of the hypothesized model. After the reliability and validity conditions were satisfied further analysis on the structural model can be performed in order to assess the predictive value of the research model.

\section{Structural model assessment}

In the process of determining the predictive value of the research model correlation analysis together with the multiple regression analysis has been conducted. The report of the correlation will include the strength of the relationship and the significance value (p). Any p-values less than .05 will indicate that the result is not due to chance. That customer orientation has a negative impact on radical innovation was not accepted. Regarding Customer orientation having a positive impact on incremental innovation, the Pearson's $r$ is close to 1 , indicating a strong relationship between the two variables. The relationship of customer orientation and incremental innovation has Pearson's r close to $1(0.889)$, indicating a strong correlation between these variables. The Sig. (2-Tailed) value of these variables is 0.000 . This value is less than .05 . Because of this, we can conclude that there is a statistically significant correlation between customer orientation and incremental innovation. The correlation between interfunctional coordination and incremental and radical innovation is high (Pearson's $r=0.777,0.698$, meaning that changes in one variable are strongly correlated with changes in the second variable. Competitor orientation and its correlation with radical and incremental innovation is respectively (Pearson's $r=0.889,0.735$ ), indicating a positive correlation and also suggesting that as one variable increases in value, the second variable also increase in value. As for the moderating effect of centralization and the correlation with all other variable, there is a week relationship between. This means that changes in one variable are not correlated with changes in the second variable. The reported values are as follows: (Pearson's correlation $=0.302$, $0.193,0.102,0.225,0.401)$ 
Table 4-1 Correlations

\begin{tabular}{|c|c|c|c|c|c|c|c|c|}
\hline & & Centralization & Formalization & $\begin{array}{l}\text { Customer } \\
\text { Orientation }\end{array}$ & $\begin{array}{l}\text { Competitive } \\
\text { Orientation }\end{array}$ & $\begin{array}{l}\text { Interfunctional } \\
\text { Orientation }\end{array}$ & $\begin{array}{l}\text { Incremental } \\
\text { innovation }\end{array}$ & $\begin{array}{l}\text { Radical } \\
\text { innovation }\end{array}$ \\
\hline \multirow[t]{3}{*}{ Centralization } & Pearson Correlation & 1 &, $610^{* * *}$ &, $302^{* *}$ & ,193 &, $102^{* *}$ &, $225^{* *}$ & ,401 \\
\hline & Sig. (2-tailed) & & ,000 & ,001 & ,045 & ,293 &, 018 & ,000 \\
\hline & $\mathrm{N}$ & 109 & 109 & 109 & 109 & 109 & 109 & 109 \\
\hline \multirow[t]{3}{*}{ Formalization } & Pearson Correlation &, $610^{* *}$ & 1 &, $480^{* *}$ &, $500^{* *}$ & ,396 &, $513^{* *}$ &, $491^{* *}$ \\
\hline & Sig. (2-tailed) & ,000 & & ,000 &, 000 &, 000 &, 000 & ,000 \\
\hline & $\mathrm{N}$ & 109 & 109 & 109 & 109 & 109 & 109 & 109 \\
\hline Customer & Pearson Correlation &, $302^{* *}$ &, $480^{* *}$ & 1 &, $879^{* *}$ &, $830^{* *}$ & ,889 &, $799^{* *}$ \\
\hline \multirow[t]{2}{*}{ Orientation } & Sig. (2-tailed) & ,001 &, 000 & & ,000 &, 000 &, 000 &, 000 \\
\hline & $\mathrm{N}$ & 109 & 109 & 109 & 109 & 109 & 109 & 109 \\
\hline Competitive & Pearson Correlation &, $193^{*}$ &, $500^{* *}$ &, $879^{* *}$ & $1^{*}$ &, $847^{* *}$ &, $889^{* *}$ &, $735^{*}$ \\
\hline \multirow[t]{2}{*}{ Orientation } & Sig. (2-tailed) &, 045 & ,000 & ,000 & &, 000 &, 000 &, 000 \\
\hline & $\mathrm{N}$ & 109 & 109 & 109 & 109 & 109 & 109 & 109 \\
\hline Interfunctional & Pearson Correlation &, 102 &, $396^{* *}$ &, $830^{* *}$ &, 847 & $1^{* *}$ &, $777^{* *}$ & ,698 \\
\hline \multirow[t]{2}{*}{ Coordination } & Sig. (2-tailed) & ,293 & ,000 & ,000 & ,000 & &, 000 & ,000 \\
\hline & $\mathrm{N}$ & 109 & 109 & 109 & 109 & 109 & 109 & 109 \\
\hline \multirow{3}{*}{$\begin{array}{l}\text { Incremental } \\
\text { innovation }\end{array}$} & Pearson Correlation &, $225^{*}$ &, $513^{* *}$ &, $889^{* *}$ &, $889^{*}$ &, $777^{* *}$ & $1^{* *}$ &, $781^{*}$ \\
\hline & Sig. (2-tailed) & ,018 &, 000 & ,000 & ,000 &, 000 & &, 000 \\
\hline & $\mathrm{N}$ & 109 & 109 & 109 & 109 & 109 & 109 & 109 \\
\hline \multirow{3}{*}{$\begin{array}{l}\text { Radical } \\
\text { innovation }\end{array}$} & Pearson Correlation &, $401^{* *}$ &, $491^{* *}$ &, $799^{* *}$ &, $735^{* *}$ &, $698^{* *}$ &, $781^{* *}$ & $1^{* * *}$ \\
\hline & Sig. (2-tailed) & ,000 & ,000 & ,000 & ,000 &, 000 &, 000 & \\
\hline & $\mathrm{N}$ & 109 & 109 & 109 & 109 & 109 & 109 & 109 \\
\hline
\end{tabular}

**. Correlation is significant at the 0.01 level (2-tailed).

*. Correlation is significant at the 0.05 level (2-tailed). 


\section{Multiple regression analysis}

Regression analysis of the effects of customer orientation, competitor orientation and interfunctional coordination on radical innovation under the moderating effects of centralization and formalization was performed using multiple linear regression in SPSS. Linear regression was confirmed considering the data had been normally distributed. Customer orientation, competitor orientation and interfunctional coordination were identified as independent predictors during the model selection, with a value of maximum adjusted $\mathrm{R} * 2=0,634$. The predictive power of the model was characterized and assessed using the R2 value (0,644). For ANOVA (Analysis Of Variance) the reported values means (M) and standard deviations (SD) for each group, F value (F), and significance level (p). For the radical innovation dependent variable showed a significance value less than .05 , meaning that the findings were statistically significant. The $F$ value was 63,378 and the degrees of freedom result was 3 . The $\mathrm{R}$ square value was 0.644 and the adjusted $\mathrm{R}$ Square value 0.634. The analysis shows that customer orientation had a negative impact on radical innovation $(\mathrm{B}=.647 \mathrm{t}=4.989)$, however competitor orientation had a significant impact on radical innovation $($ Beta $=.108, \mathrm{t}=.792)$.

Table 4-2 Market orientation impact on radical marketing innovation

Dependent variable: Radical marketing innovation

R square $=0.644$ Adjusted $R=0.634 \mathrm{~F}=63.378 \mathrm{p}<0.01$

\begin{tabular}{cccccc}
\hline & Unstandardized Beta & Std. Error & Standardized Beta & T & Sig. \\
\hline Customer orientation &, 647 &, 130 &, 647 & 4,989 & 1,000 \\
Competitor orientation &, 108 &, 136 &, 108 &, 792 &, 000 \\
Incremental coordination &, 069 &, 116 &, 069 &, 592 &, 430 \\
& & & & & \\
\hline
\end{tabular}

For the incremental innovation dependent variable showed a significance value less than .05 , meaning that the findings were statistically significant. The F value was 187,378 and the degrees of freedom result was 3 . The $\mathrm{R}$ square value was 0.843 and the adjusted $R$ Square value equaled 0.838 . Such a large F ration for variance group indicated that the variation among group means is more than can be possible by chance. Also a large $\mathrm{F}$ ratio can occur when the null hypothesis is wrong. Regarding $(\mathrm{t})$ tests, means $(\mathrm{M})$ and standard deviations (SD) were reported for each group, $t$ value $(t)$, degrees of freedom (in parentheses next to $t$ ), and significance level (p). There was a significant difference in the moderating effects of centralization $(\mathrm{M}=5.03, \mathrm{SD}=.93)$ and radical innovation $(\mathrm{M}=4.47, \mathrm{SD}=1.66)$ The least significant level of difference was found between customer orientation $(\mathrm{M}=4.67, \mathrm{SD}=1.48$ and competitor orientation $(\mathrm{M}=4.77$, $\mathrm{SD}=1.44), \mathrm{t}=4.989, \mathrm{t}=0.792$.

Table 4-3 Market orientation impact on incremental marketing innovation

Dependent variable: Incremental marketing innovation

$\mathrm{R}$ square $=0.843$ Adjusted $\mathrm{R}=0.838 \mathrm{~F}=63.378 \mathrm{p}<0.01$

\begin{tabular}{cccccc}
\hline & Unstandardized Beta & Std. Error & Standardized Beta & T & Sig. \\
\hline Customer orientation &, 498 &, 086 &, 498 & 5,776 & 1,000 \\
Competitor orientation &, 510 &, 091 &, 510 & 5,629 &, 000 \\
Incremental coordination &,- 069 &, 077 &,- 069 &,- 892 &, 000 \\
& & & & & \\
\hline
\end{tabular}

The regression model for the radical innovation dependent variable accounted for $64 \%$. For the radical innovation dependent variable, the Beta value proved to be positive for customer orientation, competitor orientation and interfunctional coordination, respectively $(\mathrm{B}=0.647,0.108,0.069$ indicating a positive relationship for all three independent variables. The regression model for the incremental innovation dependent variable accounts for $84 \%$ although the R-squared value does not indicate whether a regression model is adequate so sometimes during the data analysis it is required to resort to the adjusted R-squared compares the explanatory power of regression models that contain different numbers of predictors. For the incremental innovation dependent variable, the Beta value proved to be 
positive for customer orientation and competitor orientation $(B=0.498,0.510$ respectively) but resulted negative for interfunctional coordination $(\mathrm{B}=-0.069)$, indicating a negative relationship. The $\mathrm{Z}$-score calculated for the radical and incremental innovation dependent and independent variables, customer orientation, competitor orientation and interfunctional coordination indicated how far that data point is from the mean, given the standard deviation of the sample. All the z-score values resulted positive indicating that the score is above the mean, although there was a negative score for the competitor orientation (-0.069), indicating a value below the mean. Finally the hypotheses analysis showed that:

H1 Customer orientation has a positive impact on radical innovation, so our hypothesis is not accepted

H2 Customer orientation has a positive impact on incremental innovation is rejected

H3 Competitor orientation has a positive impact on radical innovation is rejected.

H4 Competitor orientation has a positive impact on incremental innovation is accepted

H5 Inter-functional coordination has no significant impact on incremental innovation is accepted

H6 Inter-functional coordination has a positive impact radical innovation is rejected

H7 There is a negative moderating effect of centralization on the market orientation and marketing innovation relationship is rejected

H8 There is a negative moderating effect of formalization on the market orientation and marketing innovation relationship is partially accepted

\section{Discussion and implications}

Data analysis yielded significant results, thus partially confirming the value of our research model and hypothesize relationships. The study offers important findings and contributes to the literature of marketing innovation and market orientation. First, in contrast to our expectations customer orientation had significant impact on radical innovation. We predicted it to have a negative effect. The negative influence of market orientation, especially on radical innovations, has already been detected (Bennett and Cooper 1979; Lawton and Parasuraman 1980). A customer orientation has often been criticized as constraining certain innovation processes. Nevertheless, since innovation is regarded as a knowledgebased capability, according to (Nelson, D. L. \& Quick, J. C., 2006), the execution of market-sensing, customer-relating, and customer-response capabilities lend to, rather than inhibit, innovation competencies. In describing innovation, the view taken here is on two distinct but interrelated concepts, namely creativity (i.e. idea generation and problem solving) and innovation (i.e. the implementation of creative ideas).

According to our expectations, customer orientation proved to have a strong positive impact on incremental innovation. Since the publication of Narver and Slater (2004) study, the dominant research stream that has addressed issues of customer latent and future needs is found in the market/customer orientation literature. Specifically, there was proof that customer orientation had a significant impact on incremental innovation also because according to (Narver, J. C. \& Slater, S. F., 1990), a customer orientation includes all the activities that are involved in acquiring information about customers in a market and in disseminating the information throughout the organization and also incremental innovation tends to limit the range of potential service innovation, because it relies on customers' current view of the service market (Becheikh et al., 2006) and is closely related to customer-led strategies. Such behaviours are related to gathering market intelligence about the current and future needs of customers and sharing that information throughout the firm (Gatignon, H. \& Xuereb, J. M., 1997). Proving the hypothesis of customer orientation having a positive impact on incremental innovation is in accordance with findings in previous studies we have examined.

Contrary to what we have hypothesized, competitor orientation proved to have a negative impact on radical innovation. According to Narver and Slater competitor orientation, an element of market orientation, means that "a seller understands the short-term strengths and weaknesses and long-term capabilities and strategies of both the key current 


\section{Alshahry Abdullah saeed A, Wang Aimin \\ Market Orientation Impact on Radical and Incremental Marketing Innovation: A Study of Saudi Arabia Hospital Marketing Efforts}

and potential competitors" (1990, p21-22). Prior research has also shown that, competitor oriented companies are not just trying to analyze the strengths and weaknesses of current competitors, but trying to anticipate the current competitors and potential competitors action to be done. (Qureshi, 2008). According to the aforementioned author, in mature organizations a strong competitor orientation is associated with radical innovation. According to the reviewed literature and data presented, one of the main reasons why the results have shown competitor orientation has a negative influence on radical innovation is that that a highly customer centric approach is necessary to create radical innovations and that customers of products often are ahead of the trend and are able to develop radical product and service innovations. Competitor orientation leads to incremental innovations where it gathers information about customer needs, competitors and transfers this information throughout the organization to fully exploit it. Based on this information, existing products are improved on the short term to stay ahead of competitors and also incremental innovation allows a company to keep up with competition and hold market position. Therefore, primarily we can emphasize that the two aforementioned main factors, information about customer needs and information about competitors are key for competitor orientation to have a positive influence on incremental innovation. The findings of our study suggest that there is an important role of market orientation for the successful implementation of innovation and business performance of hospitals in Saudi Arabia. The results indicated that there is a positive influence of customer orientation on radical innovation and incremental innovation, a strong positive impact of competitor orientation on incremental innovation and no significant impact regarding inter-functional coordination on both incremental and radical innovation. The moderating effect of centralization on market innovation and innovation proved to be insignificant and the formalization effect had a positive influence on the customer, competitor and interfunctional orientation and radical innovation relationship. Additionally our study is valuable (for the practice, and theory) as it assisted in developing and further elaborating the science of market orientation, particularly customer and competitor orientation and inter-functional coordination, and the influence on incremental and radical service which are relevant for the financial results of hospitals in Saudi Arabia. The contribution of this research was also to develop a conceptual and theoretical understanding on incremental and radical innovation in the effort to improve performance, especially for the Saudi Arabian hospitals. The practical implication of this study is provide insight and knowledge Saudi Arabian hospital managerial staff, in implementing the concept of market orientation in relation to innovation and overall hospital performance. Our propositions have direct managerial implications. We identified the factors that can be expected to foster or discourage a marketing innovation. These factors are largely controllable by managers and therefore can be altered by them to improve the marketing innovation and performance of their organizations. Overall, our research gives managers a comprehensive view of what a market orientation is, ways to attain it, and its likely consequences.

\section{Conclusion, limitations and future studies}

We conducted an empirical study on market orientation aspects and marketing innovation in the context of hospital work. The research model was built on the basis of thorough literature review of key factors influencing radical and incremental marketing innovation. It enables managers and researchers to better understand how to attain desired marketing innovation in hospitals and in organizations. We tested relationships between different market orientation factors and radical and incremental marketing innovation and yielded important findings. The conducted study has certain limitations. To begin with, only one perspective on market orientation was followed in the study, and some, which may also be relevant for marketing innovation, were ignored. First, we could not include all studies and constructs in the market orientation literature because of a lack of information necessary for the calculation of effect sizes. The study has not employed a triangulation of methods in order to avoid common method bias. In addition to the survey, which was conducted, meetings with hospital workers, interviews and observations undertaken would result in a deeper understanding of behavior and validation of the findings. Future research should deepen the understanding of critical success factors influencing radical and incremental marketing innovation. Furthermore, the impact on other types of innovation should be examined in the future. For instance, a particular part of the marketing mix innovations could be studied separately, such as product or promotion innovation. The studied sample should include other hospitals and health care institutions and other institutions that have a significant social role but are also that engaged in marketing activities. Past studies have focused mainly on market orientation and marketing innovation in organizations that are clearly market driven and customer oriented. Thus additional studies in all the sectors are suggested in order to validate the generalizability of our findings. 


\section{References}

- Aghion P., Burgess R., Redding S., Zilibotti F, (2008), The unequal effects of liberalization: Theory and evidence from India. American Economic Review, vol.8, no. 4, pp. 1397-1412

- $\quad$ Aiken, M., \& Hage, J. (1971). The organic organization and innovation. Sociology, 5(1), 63-82.

- Andersson, S., \& Evangelista, F. (2006). The entrepreneur in the born global firm in Australia and Sweden. Journal of Small Business and Enterprise Development, 13(4), 642-659.

- Arundel, A., Kanerva, M., van Cruysen, A., \& Hollanders, H. (2007). Innovation statistics for the European service sector. INNO Metrics, 1-43.

- Atuahene-Gima, K. (1996). Market orientation and innovation. Journal of Business Research, 35(2), 93103.

- Avlonitis, G. J., \& Salavou, H. E. (2007). Entrepreneurial orientation of SMEs, product innovativeness, and performance. Journal of Business Research, 60(5), 566-575.

- Barro R., Martine X.S. (1991), Economic growth and convergence across the United States. National Bureau of Economic Research working paper, July

- Blair, J. D., \& Boal, K. B. (1991). Strategy formation processes in health care organizations: a contextspecific examination of context-free strategy issues. Journal of Management, 17(2), 305-344.

- Basu S.R., (2006), Economic growth, well being and governance under economic informs: Evidence from Indian states. Journal of World Economic Review, vol. 1, no. 2, pp. 127-149

- Becheikh, N., Landry, R., \& Amara, N. (2006). Lessons from innovation empirical studies in the manufacturing sector: A systematic review of the literature from 1993-2003. Technovation, 26(5), 644664.

- $\quad$ Bennett, R. C., \& Cooper, R. G. (1979). Beyond the marketing concept. Business Horizons, 22(3), 76-83.

- Cardinal, L. B. (2001). Technological innovation in the pharmaceutical industry: The use of organizational control in managing research and development. Organization Science, 12(1), 19-36.

- Chiesa, V., \& Frattini, F. (2011). Commercializing Technological Innovation: Learning from Failures in High-Tech Markets*. Journal of Product Innovation Management, 28(4), 437-454.

- Claessens S., Laeven L., (2003), Financial development, property rights and growth. The Journal of Finance, vol. 58, no. 6, pp. 2410-2436

- Cooper, M. C., \& Ellram, L. M. (1993). Characteristics of supply chain management and the implications for purchasing and logistics strategy. The International Journal of Logistics Management, 4(2), 13-24.

- Craig, A., \& Hart, S. (1992). Where to now in new product development research?. European Journal of Marketing, 26(11), 2-49.

- Daft, R. L., \& Weick, K. E. (1984). Toward a model of organizations as interpretation systems. Academy of management review, 9(2), 284-295.

- Damanpour, F. (1991). Organizational innovation: A meta-analysis of effects of determinants and moderators. Academy of management journal, 34(3), 555-590.

- $\quad$ Davis, D. D., \& Holt, C. A. (1994). Market power and mergers in laboratory markets with posted prices. The RAND Journal of Economics, 467-487.

- Day, G. S., \& Wensley, R. (1988). Assessing advantage: a framework for diagnosing competitive superiority. The Journal of Marketing, 1-20.

- De Jong, J. P., Bruins, A., Dolfsma, W., \& Meijaard, J. (2003). Innovation in service firms explored: what, how and why. EIM Business Policy Research, Strategic Study B200205, 18.

- Deshpande, R., \& Zaltman, G. (1982). Factors affecting the use of market research information: A path analysis. Journal of marketing research, 14-31.

- Dess, G. G., Ireland, R. D., \& Hitt, M. A. (1990). Industry effects and strategic management research. Journal of management, 16(1), 7-27.

- Drejer, I. (2004). Identifying innovation in surveys of services: a Schumpeterian perspective. Research policy, 33(3), 551-562. 
- $\quad$ Easterly W., Rebelo S., (1993), Fiscal policy and economic growth. Journal of Monetary Economics, pp. 417-458

- Gatignon, H., \& Xuereb, J. M. (1997). Strategic orientation of the firm and new product performance. Journal of marketing research, 77-90.

- Gopalakrishnan, S., \& Damanpour, F. (1994). Patterns of generation and adoption of innovation in organizations: Contingency models of innovation attributes. Journal of Engineering and Technology Management, 11(2), 95-116.

- Greenaway D., Morgan C.W., Wright P., (1998), Trade liberalization and growth in developing countries: some new evidence. World Development, vol. 25, pp.1885-1892

- Grönroos, C. (2006). Adopting a service logic for marketing. Marketing theory, 6(3), 317-333.

- Hall, R. H., Johnson, N. J., \& Haas, J. E. (1967). Organizational size, complexity, and formalization. American Sociological Review, 903-912.

- Hauknes, J. (1998). Services in innovation-Innovation in services (No. 199813). The STEP Group, Studies in technology, innovation and economic policy.

- Henard, D. H., \& Szymanski, D. M. (2001). Why some new products are more successful than others. Journal of marketing Research, 38(3), 362-375.

- Hende, E. A., \& Schoormans, J. P. (2012). The story is as good as the real thing: Early customer input on product applications of radically new technologies. Journal of Product Innovation Management, 29(4), 655-666.

- Hurley, R. F., \& Hult, G. T. M. (1998). Innovation, market orientation, and organizational learning: an integration and empirical examination. The Journal of Marketing, 42-54.

- Im, S., \& Workman Jr, J. P. (2004). Market orientation, creativity, and new product performance in hightechnology firms. Journal of marketing, 68(2), 114-132.

- Inklaar, R., Timmer, M. P., \& Van Ark, B. (2008). Market services productivity across Europe and the US. Economic Policy, 23(53), 140-194.

- Jansen, J. J., Van Den Bosch, F. A., \& Volberda, H. W. (2006). Exploratory innovation, exploitative innovation, and performance: Effects of organizational antecedents and environmental moderators. Management science, 52(11), 1661-1674.

- Jansson, H., \& Sandberg, S. (2008). Internationalization of small and medium sized enterprises in the Baltic Sea Region. Journal of International Management, 14(1), 65-77.

- Jaworski, B. J., \& Kohli, A. K. (1993). Market orientation: antecedents and consequences. The Journal of marketing, 53-70.

- Kanbur R. Zhang X. (2005), Spatial inequality in education and health care in China. China Economic Review, vol. 16, pp. 189-204

- Kaufmann D, Kraay A., Mastruzzi M. (2007), Governance matters VI: Governance indicators for 19962006. World Bank Policy Research Paper, pp. 4280

- Khandwalla, P. N. (1977). The design of organizations.

- Kohli, A. K., \& Jaworski, B. J. (1990). Market orientation: the construct, research propositions, and managerial implications. The Journal of Marketing, 1-18.

- Krishna K.L. (2004), Patterns and determinants of economic growth in India. Working Paper, 144. CRIER. New Delhi

- Kumar, V., Jones, E., Venkatesan, R., \& Leone, R. P. (2011). Is market orientation a source of sustainable competitive advantage or simply the cost of competing?. Journal of Marketing, 75(1), 16-30.

- Lawton, L., \& Parasuraman, A. (1980). The impact of the marketing concept on new product planning. The Journal of Marketing, 19-25.

- $\quad$ Leifer, R., O'Connor, G. C., \& Rice, M. (2001). Implementing radical innovation in mature firms: The role of hubs. The Academy of Management Executive, 15(3), 102-113.

- Li, T., \& Calantone, R. J. (1998). The impact of market knowledge competence on new product advantage: conceptualization and empirical examination. The Journal of Marketing, 13-29.

- Lukas, B. A., \& Ferrell, O. C. (2000). The effect of market orientation on product innovation. Journal of the academy of marketing science, 28(2), 239-247. 
- Lukas, B. A., \& Menon, A. (2004). New product quality: intended and unintended consequences of new product development speed. Journal of Business Research, 57(11), 1258-1264.

- March, J. G., \& Simon, H. A. (1958). Organizations.

- McDermott, C. M., \& O'Connor, G. C. (2002). Managing radical innovation: an overview of emergent strategy issues. Journal of product innovation management, 19(6), 424-438.

- Moorman, C., Zaltman, G., \& Deshpande, R. (1992). Relationships between providers and users of market research: The dynamics of trust. Journal of marketing research, 29(3), 314-328.

- Morgan, R. M., \& Hunt, S. D. (1994). The commitment-trust theory of relationship marketing. the journal of marketing, 20-38.

- Narver, J. C., \& Slater, S. F. (1990). The effect of a market orientation on business profitability. The Journal of Marketing, 20-35.

- Nelson, D. L., \& Quick, J. C. (2006). Organizational Behavior: Foundations. Realities\& Challenges, 5th ed., Thomson, 636.

- Normann, R. (1971). Organizational innovativeness: Product variation and reorientation. Administrative Science Quarterly, 203-215.

- $\quad$ Palmatier, R. W., Jarvis, C. B., Bechkoff, J. R., \& Kardes, F. R. (2009). The role of customer gratitude in relationship marketing. Journal of marketing, 73(5), 1-18.

- $\quad$ Perols, J., Zimmermann, C., \& Kortmann, S. (2013). On the relationship between supplier integration and time-to-market. Journal of Operations Management, 31(3), 153-167.

- Pinto, M. B., \& Pinto, J. K. (1990). Project team communication and cross-functional cooperation in new program development. Journal of Product Innovation Management, 7(3), 200-212.

- $\quad$ Pomfret R., Anderson K.H. (1997), Uzbekistan: Welfare impact of slow transition. World Institute for Development Economic Research, pp. 135

- $\quad$ Qureshi, A. (2008). Plugging Into Energy Market Diversity. In HotNets (pp. 49-54).

- Rao, H., \& Dewar, R. D. (2006). Building a market-focused culture of human resource, 172.

- Sachs J.D., Warner A.M., (1995), Economic reforms- the process of global integration. Brookings Papers on Economic activity, vol. 1, pp.1-118

- Sainio, L. M., Ritala, P., \& Hurmelinna-Laukkanen, P. (2012). Constituents of radical innovationexploring the role of strategic orientations and market uncertainty. Technovation, 32(11), 591-599.

- Salomo, S., Weise, J., \& Gemünden, H. G. (2007). NPD planning activities and innovation performance: the mediating role of process management and the moderating effect of product innovativeness. Journal of product innovation management, 24(4), 285-302.

- Sheremata, W. A. (2000). Centrifugal and centripetal forces in radical new product development under time pressure. Academy of management review, 25(2), 389-408.

- Sivadas, E., \& Dwyer, F. R. (2000). An examination of organizational factors influencing new product success in internal and alliance-based processes. Journal of marketing, 64(1), 31-49.

- Spreng, R. A., MacKenzie, S. B., \& Olshavsky, R. W. (1996). A reexamination of the determinants of consumer satisfaction. The Journal of Marketing, 15-32.

- Tether, B. S. (2005). Do services innovate (differently)? Insights from the European Innobarometer Survey. Industry \& Innovation, 12(2), 153-184.

- Tether, B., \& Howells, J. (2007). Changing understanding of innovation in services. Innovation in Services, 9, 21-60.

- Thorbecke E., Wan H., (2004), Revisiting East Asia's development model. Cornell Conference on the Seventy Five Years of Development, Ithaca, May 2004

- Vega-Jurado, J., Gutiérrez-Gracia, A., Fernández-de-Lucio, I., \& Manjarrés-Henríquez, L. (2008). The effect of external and internal factors on firms' product innovation. Research policy, 37(4), 616-632.

- Veryzer, R. W. (2005). The roles of marketing and industrial design in discontinuous new product development*. Journal of Product Innovation Management, 22(1), 22-41.

- Zaltman, G., Pinson, C. R., \& Angelmar, R. (1973). Metatheory and consumer research. Holt, Reinhart and Winston. 
- Zhou, K. Z., Li, J. J., Zhou, N., \& Su, C. (2008). Market orientation, job satisfaction, product quality, and firm performance: evidence from China. Strategic Management Journal, 29(9), 985-1000. 